\title{
Artigo
}

\section{Teoria das relações internacionais: a pluralidade absoluta e a pluralidade relativa da disciplina}

\author{
International relations theory: the absolute plurality and \\ the relative plurality of the discipline \\ DOI: 10.5752/P.1809-6182.2016v13.n3.p196
}

Daniel Costa Gomes ${ }^{1}$

\section{RESUMO}

Recebido em: 23 de fevereiro de 2016 Aprovado em: 04 de junho de 2016

O presente trabalho é um estudo sobre a disciplina Teoria das Relaçóes Internacionais. Tem-se por objetivo analisar se a evoluçáo histórica da disciplina tem resultado em maior pluralidade no estudo das Relaçóes Internacionais. Para verificar isso, o artigo é dividido em duas partes, em que se analisam, respectivamente, a narrativa tradicional e as novas narrativas na disciplina. Foram formulados dois conceitos: pluralidade absoluta e pluralidade relativa. Duas conclusóes principais são alcançadas. A primeira: numericamente, a disciplina Teoria das Relaçôes Internacionais se tornou mais plural, em decorrência do surgimento de teorias, de cursos de graduação e de programas de pós-graduação, por exemplo. Assim, constata-se pluralidade absoluta. A segunda conclusão: a diversidade, conceituada como pluralidade relativa, ainda não se consolidou. Afinal, as novas teorias geralmente constituem variantes dos mesmos matizes, a lingua inglesa continua a dominar na literatura especializada, e as novas formas de pensar as Relaçóes Internacionais normalmente são consideradas não científicas.

Palavras-chave: Teoria das relaçóes internacionais. Evolução. Pluralidade.

\section{ABSTRACT}

This paper is a study of the International Relations Theory discipline. The objective is to analyze whether the evolution of the discipline has resulted in greater plurality in the study of International Relations. In order to verify this, the paper is divided into two parts, wherein the traditional thinking and the new ways of thinking of the discipline are respectively analysed. Two concepts were coined: absolute plurality and relative plurality. Two conclusions are reached. The first: numerically, the International Relations Theory discipline has become more plural as a result of the appearance of theories, and of graduate and postgraduate courses, for instance. Consequently, absolute plurality is verified. The second conclusion: the diversity of the discipline, translated into relative plurality, has not been consolidated yet. After all, the new theories are generally variations within the same patterns, English continues to be the dominant language in specialised literature, and the new ways of thinking International Relations are normally regarded as non scientific.

Key-words: International relations theory. Evolution. Plurality.

1. Mestre em Relações Internacionais pela UnB, graduação em Direito pela Universidade Federal da Paraíba. OR-

CID: orcid.org/0000-0002-2104-1376 


\section{Introdução}

Tomando-se pluralidade como a qualidade daquilo que não é único ou daquilo que está em quantidade não desprezível, inquirir se há, nos dias atuais, pluralidade no estudo das Relaçóes Internacionais parece uma pergunta retórica, dada a disseminação de teorias, de cursos e de periódicos de Relaçóes Internacionais. No Brasil, por exemplo, o primeiro curso de graduação em Relaçóes Internacionais foi criado em 1974, na Universidade de Brasília, e o segundo demorou mais de uma década para ser criado, no final dos anos 1980 (LESSA, 2005). Na década de 1990, houve um incremento significativo na quantidade de cursos de graduação em Relaçóes Internacionais, tendência que continuou, mas com menor fôlego, na década de 2000, para alcançar o número de 112 em 2010 (RIBEIRO; KATO; RAINER, 2013).

Uma análise mais detida sobre o significado de pluralidade, no entanto, revela que a resposta a essa pergunta é mais complexa do que pode parecer à primeira vista. Argumenta-se, ao longo do presente artigo, que, embora seja possível falar em pluralidade absoluta das Relaçóes Internacionais, o fenômeno da pluralidade relativa ainda não se afirmou na disciplina.

Por pluralidade absoluta, entende-se o processo resultante do aumento da quantidade (de teorias, de periódicos, de artigos, de filiados a associaçốes, de cursos de graduação, de programas de pós-graduação, de estudantes). Assim, a formulação de novas abordagens teóricas sob as matrizes existentes, a exemplo do realismo e do liberalismo, constitui manifestação de pluralidade absoluta, pois há acréscimo numérico de perspectivas teóricas. A criaçáo de cursos de graduação e de programas de pós-graduação em Relações Internacionais implica pluralidade absoluta. A publicação de mais artigos e a criação de novos periódicos na área de Relaçôes
Internacionais são manifestaçôes da pluralidade absoluta. $\mathrm{O}$ acréscimo de filiados a associações de profissionais na área, como a International Studies Association (ISA), é percebido como um exemplo da afirmação da pluralidade absoluta.

Por pluralidade relativa, entende-se o processo resultante do aumento da diversidade (de línguas adotadas, de nacionalidade dos autores e dos co-autores dos artigos, de origem dos periódicos reconhecidos como importantes pela comunidade epistêmica, de matrizes teóricas, de literatura nas grades curriculares). Assim, uma distribuição equitativa entre as línguas (inglês, francês, português, espanhol, mandarim, por exemplo) na produção científica seria coerente com a ideia de pluralidade relativa. Uma proporcionalidade entre as nacionalidades na literatura - por exemplo, caso a produção acadêmica latino-americana e a africana fossem proporcionais à norte-americana e à da Europa Ocidental - também implicaria a afirmação do fenômeno da pluralidade relativa. Igualmente, a pluralidade relativa seria verificada caso os periódicos considerados influentes pela comunidade epistêmica das Relaçôes Internacionais fossem de nacionalidades diversas. $\mathrm{O}$ aumento de teorias para além das matrizes teóricas correntes seria uma manifestaçáo da pluralidade relativa. Ainda, afirmar-se-ia a pluralidade relativa caso a literatura nos currículos dos cursos de Relaçóes Internacionais ou a estrutura desses cursos apresentassem uma distribuição equilibrada de nacionalidades ou uma preponderância da literatura local - por exemplo, caso os cursos de Relaçôes Internacionais na Ásia apresentassem uma distribuição equitativa em termos da nacionalidade da literatura utilizada ou que a origem asiática fosse a mais presente nessa literatura.

Para analisar as Relaçôes Internacionais sob as lentes da pluralidade absoluta e da pluralidade relativa, o presente artigo divide-se em três partes, além desta introdução. $\mathrm{Na}$ primeira parte, analisa-se a 
narrativa tradicional sobre as Relaçóes Internacionais. Dessa forma, são mencionados os debates, os paradigmas, o surgimento de novas teorias e o questionamento sobre o fim das teorias.

$\mathrm{Na}$ segunda parte, a narrativa tradicional é posta em perspectiva. Assim, são apresentadas, incialmente, algumas das críticas à narrativa tradicional sobre as Relaçóes Internacionais. Posteriormente, são citadas algumas das estratégias para se produzir novas narrativas, bem como são elencados alguns dos desafios enfrentados para se alcançar essas novas narrativas.

$\mathrm{Na}$ parte final, a seu turno, são apresentadas as conclusões.

\section{A narrativa tradicional}

No presente trabalho, conceitua-se como narrativa tradicional das Relaçóes Internacionais aquela que analisa a disciplina sob a perspectiva dos debates e dos paradigmas. Essa perspectiva registra o processo de evolução cronológica das teorias das Relações Internacionais, demonstrando como elas foram formuladas, bem como a maneira pela qual elas rivalizaram entre si. Desse modo, verifica-se um processo de afirmação da pluralidade da disciplina Teoria das Relaçóes Internacionais à medida que novas teorias foram sendo elaboradas, tornando a disciplina plural. Esse processo, como lembra Kahler (1997, p. 21, tradução nossa), ganhou significativo estímulo com o fim da Guerra Fria, que "diminuiu as barreiras ideológicas para a construção de um campo que seja genuinamente internacional". Além isso, por ter gerado mudanças profundas no sistema internacional, o fim da Guerra Fria também reforçou a pluralidade da Teoria das Relaçóes Internacionais pelo interesse em explicar essas mudanças (DOYLE; IKENBERRY, 1997, p. 279).

No entanto, a pluralidade das Relações Internacionais é demonstrada antes mesmo de se iniciar a narrativa - ou seja, antes mesmo de se iniciar a exposição das teorias. Afinal, não há consenso sobre como identificar as teorias nem como agrupálas - ou seja, não há consenso sobre quais são os debates ou os paradigmas. Jackson e Nexon (2009) vão além e questionam a própria existência dos $p a-$ radigmas. Assim, propóem a substituição do termo paradigma, de Thomas Kuhn, por tipo ideal, de Max Weber. Aplicada essa substituiçáo, seria possível comparar realismo, liberalismo e construtivismo em relação a pontos específicos, superando a incomensurabilidade característica da definiçấo de paradigma, de Kuhn. Para Waever (1997), os conceitos de debate e de paradigma são úteis (facilitam a classificação das teorias e o [primeiro] acesso a elas), mas não verdadeiros (são caricaturais, pois quase nenhuma teoria se encaixa nesses rótulos; acabam ignorando muitas teorias que têm sido produzidas e que não se encaixam nessas caracterizações).

\section{A pluralidade pelos debates e dos debates}

Iniciando-se propriamente a narrativa tradicional, tem-se que o primeiro debate é formado pela oposição, nos anos 1940, entre idealismo e realismo, seguindo a definição proposta por Edward Hellet Carr, conforme lembram Nogueira e Messari (2005). O segundo debate opóe behaviorismo e tradicionalismo, nos anos 1960. O terceiro debate (ou o debate interparadigmático), emergindo em meados da década de 1970, é entre realismo, teoria da interdependência e neomarxismo.

Na década de 1980, surge uma nova divisão: racionalistas contra reflexivistas, segundo tipologia apresentada por Keohane (1988) e cujas definições são apresentadas no próximo parágrafo. Para Lapid (1989), trata-se do terceiro debate. Para Waever (1997), no entanto, essa divisão não teria semelhanças com a verificada na década anterior. Por esse motivo, ele classifica essa divisão como quarto debate. Para Waever (1997), o terceiro debate seria o 
debate interparadigmático, no qual realismo, liberalismo interdependente e neomarxismo reconheceram-se como incomensuráveis - em outros termos, seriam distintos ontologicamente ${ }^{2}$ e, por isso, não poderiam ser comparados entre si.

No quarto debate (WAEVER, 1997), entretanto, institucionalismo neoliberal e neorrealismo são associados ao positivismo ${ }^{3}$, pelo que são classificados como racionalistas (KEOHANE, 1988). É a sintese neo-neo, que agrupa institucionalismo neoliberal e neorrealismo (BALDIN, 1993; WEAVER, 1996). Em oposição aos racionalistas, encontram-se os reflexivistas, que, para Keohane (1988), recorreram a métodos não positivistas, cujo objeto de estudo é a interpretação de normas e regimes e a constituição mútua entre instituiçôes e atores. Waever (1997) ainda acrescenta que, na década de 1980, paralelamente a esse quarto debate (4a), entre racionalistas e reflexivistas; surgiu outro (4b), entre neorrealistas e neoliberais institucionalistas. Em relação a este debate $4 \mathrm{~b}$, verifica-se uma disputa no interior polo racionalista, na qual neorrealistas defendem a relevância dos ganhos relativos, enquanto neoliberais institucionalistas advogam a importância dos ganhos absolutos.

Independentemente da classificação, a discussão em torno dos debates demonstra a plu-

2. Ontologia pode ser definida como "doutrina que estuda os caracteres fundamentais do ser” (ABBAGNANO, 2007, p. 662). No caso específico, trata-se do questionamento acerca dos elementos constituintes da realidade, de modo a inquirir se existe uma realidade objetiva universal.

3. O modelo positivista de ciência está embasado na ideia de que "o conhecimento científico emerge, apenas, com a coleta de dados observáveis. [...] [Essa coleta] levaria à identificação de padróes que, por sua vez, permitiriam a formulação de leis" (KURKI; WIGHT, 2013, p. 18, tradução nossa). Por muito tempo (e até hoje, para alguns), o modelo positivista foi considerado como o único capaz de produzir conhecimento realmente científico.

4. Nota-se que tanto a associação dessas correntes teóricas ao positivismo quanto a classificação delas como racionalistas contêm um caráter valorativo - no mínimo, implícito. Afinal, se institucionalismo neoliberal e neorrealismo são teorias "racionais" e "científicas" (pois positivistas), é lícito concluir que elas seriam teorias melhores que as outras (reflexivistas e não positivistas), segundo essa classificação de Keohane (1988). ralidade da disciplina Teoria das Relações Internacionais. Afinal, essa discussão é um epifenômeno do processo principal de emergência de novas teorias - em outros termos, a discussão em torno dos debates é um acontecimento acessório ao acontecimento principal da emergência de novas teorias. Assim, essa discussão só existe por ter havido um processo contínuo de formulação de novas teorias - e quanto mais teorias surgiram, mais a disciplina Teoria das Relações Internacionais tornou-se plural e, consequentemente, mais foi afirmando-se sua pluralidade.

Revelador dessa pluralidade é o título do artigo de Walt (1998), International Relations: One World, Many Theories. Nele, Walt afirma que o debate na disciplina está divido entre três polos: realismo, liberalismo e abordagens radicais - inicialmente marxismo, mas, depois do ocaso soviético na Guerra Fria, construtivismo. Esse título, no entanto, não corresponde exatamente ao argumento desenvolvido por Walt (1998). Afinal, quando se fala em "muitas teorias", a mensagem que se depreende é a de que haveria muitas maneiras igualmente válidas de se analisar o mundo. Ao longo do artigo, contudo, Walt (1998) defende a superioridade do realismo, reputado a teoria que ofereceria a melhor análise. Por esse motivo, ainda mais fiel à situação da disciplina é o título de outro artigo, One World, Rival Theories (SNYDER, 2004), embora nele também se reconheça a superioridade do realismo. De toda forma, tanto Walt (1998) quanto Snyder (2004) reconhecem que todas as teorias são incompletas. Assim, os formuladores de política externa estâo mais bem preparados para a realidade se forem cientes dessa diversidade teórica.

\section{Institucionalismo}

No período posterior à Guerra Fria, ganhou força a teoria liberal institucionalista. Como seu nome sugere, o elemento basilar dessa perspectiva 
teórica são as instituiçóes, que seriam "um arranjo específico, formal ou informalmente organizado, construído pelo homem" (KEOHANE, 1998bc, p. 432). Essas instituiçóes seriam capazes de tornar as relações internacionais mais estáveis e pacíficas, reduzindo a incerteza e os riscos entre os Estados (KEOHANE, 1982, p. 345-346). Ao promoveram a correlaçẫo entre diversos assuntos (issue linkage), as instituiçóes diminuem os riscos de que os Estados trapaceiem os regimes internacionais, uma vez que determinado Estado estará menos tentado a trapacear se a trapaça em um assunto de menor interesse puder afetar outro assunto, de maior interesse (KEOHANE, 1982, p. 346). As instituições contribuem para fomentar a cooperação entre os Estados devido também ao compartilhamento e à disponibilização de informaçóes, o que reduz a possibilidade de ocorrer o Dilema do Prisioneiro, no qual os atores envolvidos, devido à falta de informação, obtêm um resultado pior para todos, embora ajam racionalmente (KEOHANE, 1984, p. 69).

A oposição a essa perspectiva é empreendida, por exemplo, por Mearsheimer (1994-1995), ao defender que os liberais institucionalistas não incorporam em seu modelo a questão dos ganhos relativos. Isso thes impediria de verificar que as instituições são apenas um reflexo da balança de poder, de modo que elas não conseguem garantir a estabilidade internacional. Mearsheimer (19941995) argumenta, inclusive, que a incapacidade de as instituiçôes promoveram a paz seria algo demonstrado pela evidência empírica.

Em oposição, Keohane (1995) e Ruggie (1995) também se valem da evidência empírica para argumentar que as instituiçóes podem contribuir para a estabilidade internacional, citando os exemplos da União Europeia (UE), da Organização do Tratado do Atlântico Norte (OTAN) e da cooperação na questão da não proliferação nuclear. Esses exemplos demonstram, segundo Keohane (1995), que a busca de ganhos relativos não é o objetivo primordial dos Estados. Além disso, Keohane (2012) registra a variável da influência da política doméstica - inclinada à defesa do legalismo mesmo nos regimes internacionais - sobre a atuação internacional; e a da capacidade dos Estados de aprender com a experiência, o que permite a constatação de que muitas das desconfianças mútuas são infundadas. Essas duas variáveis (política doméstica e capacidade de aprender), ignoradas pelo realismo ofensivo de Mearsheimer (1994-1995), também reforçam a argumentação de que as instituições contribuem para a estabilidade mundial. Assim, Ruggie (1995) informa que perspectivas como a de Mearsheimer (1994-1995) são não apenas falhas, mas também perigosas para a segurança mundial.

Wendt (1995) também se opóe ao realismo ofensivo de Mearsheimer (1994-1995), mas por uma perspectiva diferente. Ele contesta o argumento neorrealista de que a estrutura internacional é formada pela distribuição das capacidades materiais ${ }^{5}$. Defendendo o construtivismo estruturalista, Wendt (1995) afirma que as relações internacionais são caracterizadas por estruturas sociais, compostas, a seu turno, por conhecimentos compartilhados, recursos materiais e práticas. Dessa forma, agente e estrutura são mutuamente constituídos, de modo que essa característica de coconstituição ${ }^{6}$ permite, inclusive, a cooperaçáo institucio-

5. De acordo com o neorrealismo de Waltz (1979, p. 97-98), os Estados dependem apenas de si para alcançarem seus objetivos no contexto de um sistema internacional anárquico, onde náo há uma autoridade que lhes seja hierarquicamente superior. A concretização desses objetivos dependerá do poder individual dos Estados, que, por sua vez, é estimado pela distribuição relativa das capacidades materiais. Assim, não importa a capacidade material absoluta dos Estados, mas sua capacidade relativa (quanto cada Estado tem comparativamente aos outros). Por esse motivo, é a distribuiçáo das capacidades materiais que determina quem são os detentores de poder no sistema internacional anárquico e, consequentemente, a estrutura desse sistema internacional.

6. Em oposiçáo à constituição - caracterizada por uma relaçấo em que, por exemplo, a estrutura determina as características do agente, sem sofrer nenhuma influência deste -, na co-constituiçáo, "agentes e estruturas [são utilizados] para explicar algumas das 
nal entre os Estados, segundo a fórmula "anarquia [cooperativa ou conflitiva] é o que os Estados fazem dela" (WENDT, 1992).

\section{Construtivismo}

O construtivismo emergiu nas Relaçóes Internacionais com os trabalhos seminais de Nicholas Onuf, Worlds of our making, de 1989; de Friedrich Kratochwil, Rules, norms, and decisions, de 1989; e de Alexander Wendt, Anarchy is what states make of it, de 1992. O fundamento desta corrente é a ideia de que agente e estrutura são co-constituídos em uma relaçáo mútua - ou seja, os sujeitos internacionais contribuem para a formação do sistema internacional, mas também são condicionados pelo mesmo sistema. Em consequência, essa perspectiva diferencia-se da apresentada por Waltz (2008), que, embora admita a influência mútua entre agente e estrutura, reconhece uma relação de subordinação entre esses dois elementos, com superioridade da estrutura. Além disso, Wendt (1987, p. 343) critica o "reducionismo ontológico" do neorrealismo de Waltz (1979), que define as estruturas, exclusivamente, como a distribuição das propriedades dos agentes pré-existentes; e os agentes, como entidades homogêneas. Como consequência desse "reducionismo ontológico" (WENDT, 1987, p. 343), não há espaço para que a estrutura crie novos agentes, nem que sejam teorizadas as relaçóes sociais (que pressupóem a existência de agentes individualizados, com propriedades causais distintas).

Mesmo compartilhando essa crença comum, existem, entretanto, diversas variaçóes

propriedades principais de cada como efeitos do outro, para ver agentes e estruturas como 'codeterminados' ou entidades 'mutuamente constituídas' " (WENDT, 1987, p. 339, tradução nossa). Assim, "cada um [agente ou estrutura] é, em certo sentido, um efeito do outro, eles são 'codeterminados'. As estruturas sociais são o resultado das consequências intencionais e não intencionais das açốes humanas, da mesma forma que essas ações humanas pressupóem ou são mediadas por um irredutível contexto estrutural" (WENDT, 1987, p. 360, tradução nossa). de construtivismo, que podem ser agrupadas, segundo a narrativa tradicional do campo, em dois polos extremos (correntes positivistas e correntes pós-positivistas), admitindo-se a possibilidade de um contínuo entre esses polos. Para Onuf (2013), por exemplo, o construtivismo significa um meio termo entre o positivismo (que exige um método específico, universal e único para se alcançar o conhecimento) e o radicalismo epistemológico pós-modernista (que aceita como válidos todos os métodos de se produzir conhecimento). Wendt (1995, p. 75), no entanto, afirma que os construtivistas são modernistas, na medida em que "endossam o projeto científico de falsear teorias contra evidências". Nesta linha, encontram-se talvez Finnemore e Sikkink (2001), que, inclusive, refutam a tese de Keohane (1988) de que os construtivistas não possuem programas de pesquisa empiricos. Guzzini (2013a), a seu turno, informa que o construtivismo é, essencialmente, uma metateoria ${ }^{7}$, o que implica uma linha construtivista diferente da explorada por Wendt (1995).

Verifica-se, dessa forma, que, enquanto Walt (1998) fala em "um mundo, muitas teorias" e Snyder (2004), em "um mundo, teorias rivais", o argumento apresentado por Wendt $(1992,1995)$ demonstra que há uma questão ainda mais profunda que a multiplicidade ou a rivalidade das teorias. Trata-se do questionamento da possibilidade de o mundo ser mesmo único. Nesse sentido, Onuf (2013), por exemplo, fala nos muitos mundos das Relações Internacionais.

Assim, surgem, no âmbito da disciplina de Relaçôes Internacionais, as discussôes em torno da existência de uma realidade objetiva externa

7. Metateoria pode ser entendida como a teoria sobre as teorias, pois, conforme Kurki e Wight (2013, p. 14, traduçáo nossa), "metateoria não assume como seu objeto de análise determinado evento, fenômeno ou conjunto de práticas empíricas do mundo real, mas explora as premissas básicas de todas as teorias e procura entender as consequências dessas premissas sobre o ato de teorização e sobre a prática da pesquisa empírica”. 
(questionamento ontológico ${ }^{8}$ ) e da possibilidade de o pesquisador alcançar essa realidade de forma neutra (questionamento epistemológico ${ }^{9}$ ). Para capturar analiticamente esses questionamentos, Keohane (1988) propóe a divisão entre as teorias racionalista e reflexivista. Grosso modo, as perspectivas racionalistas têm por premissa a existência de uma realidade objetiva externa (um mundo), que seria revelada por meio da investigação científica, que é neutra. As perspectivas reflexivistas, por sua vez, questionam a existência tanto de uma realidade objetiva quanto da neutralidade científica.

Embora Waever (1997) caracterize as correntes reflexivistas como perspectivas pós-modernistas, Wendt (1995) alerta que pós-modernismo é apenas uma das espécies do gênero das teorias críticas, que abrangem, igualmente, construtivismo, neomarxismo, feminismo. A especificação é importante, pois reconhece que, no próprio conjunto de teorias críticas, há uma divisão entre modernistas e pós-modernistas, relativa à questão da existência de conhecimento objetivo. Assim, construtivismo não se confunde com teorias críticas nem com teorias pós-modernistas.

\section{Feminismo}

Como mencionado por Wendt (1995), o construtivismo não é o único representante das teorias críticas - ou das correntes reflexivistas, segundo a tipologia de Keohane (1988). Nesse grupo, tem ganhado destaque e expressão a teoria feminista das Relaçóes Internacionais. Registre-se que, apesar de estar mencionada no singular, essa teoria comporta diversas variaçōes, como lembram Tickner (1997) e Steans (2002).

8. Para além da caracterização de Abbagnano (2007, p. 662), ontologia pode ser definida como a "teoria do ser: do que o mundo é feito? quais objetos estudamos?” (KURKI; WIGHT, 2013, p. 15 , tradução nossa).

9. Segundo Kurki e Wight (2013, p. 15, traduçáo nossa), epistemologia é a "teoria do conhecimento: como chegamos a ter conhecimento sobre o mundo?".
Assim como as outras correntes reflexivistas, a teoria feminista compartilha da crítica à epistemologia e à ontologia positivistas. No entanto, ela difere das outras correntes reflexivistas pela introdução de uma nova unidade de análise das relações internacionais, nomeadamente o gênero. A utilização dessa variável é considerada a maior inovação e o principal desafio para afirmação teórica do feminismo. Para Keohane (1998a), todavia, o maior desafio que se póe à teoria feminista é a falta de método científico, de programa de pesquisa - o que denuncia a filiação "positivista" de Keohane (1998a) e sua falta de compreensão das críticas postas pela teoria feminista.

A teoria feminista surge de uma percepção de que há uma exclusão da mulher da política internacional. Segundo Tickner (1995), essa exclusão deve-se não só à discriminação, mas também à própria construção da disciplina das Relações Internacionais, que tem privilegiado conceitos associados à masculinidade. A título ilustrativo, citam-se alguns desses conceitos e, em parênteses, seus opostos, associados à feminilidade: objetividade (em oposição a subjetividade), razão (em oposição a emoção), autonomia (em oposição a dependência), público (em oposição a privado), imposição (em oposição a diálogo), fato (em oposição a valor). Para Keohane (1998a), essas dicotomias são equivocadas (atrasadas), pois já teriam sido solucionadas (superadas) pela disciplina. Para as feministas, no entanto, a formulação das teorias clássicas das Relaçôes Internacionais, a exemplo do realismo de Morgenthau, tem ocorrido pela rejeiçấo de características femininas e, em consequência, da própria mulher.

Tickner (1995, 1997), dessa forma, denuncia essa percepção de Keohane (1998a) como enviesada, embora essa percepção se apresente como neutra. Assim, sua denúncia corresponde também a uma crítica à própria objetividade da ciência (questionamento epistemológico), propondo a 
formulação de uma teoria que comporte o gênero feminino. Para Tickner (1995, 1997), uma teoria feminista incorpora benefícios não apenas para as mulheres, mas para a própria relação entre os países e no interior desses. A reformulação do conceito de segurança nacional de uma perspectiva da força militar para a segurança do indivíduo é um exemplo da proposta de Tickner $(1995,1997)$ de alterar a percepção das relações internacionais de uma perspectiva puramente masculina. Essa modificação, segundo a autora, permitiria solucionar o paradoxo da existência de naçóes sem guerras internacionais, mas com elevados índices de homicídios nacionais, a exemplo do Brasil e de Honduras.

Steans (2002), a seu turno, analisa o fenômeno da governança global e da globalização segundo a teoria feminista das Relaçôes Internacionais. Reforçando a questão da insegurança individual intrínseca ao atual conceito de segurança nacional, Steans (2002) afirma que a globalização tem impactado as mulheres de maneira dúbia, pois, por um lado, tem contribuído para seu empobrecimento e, ao mesmo tempo, aumentado a precarização do trabalho feminino, principalmente pela redução do Estado de Bem-Estar, o que impóe à mulher a assunção da assistência aos familiares. Em outros termos, como o Estado não estaria mais provendo esses serviços, o provimento dessa assistência teria recaído sobre a mulher. Por outro lado, a globalização tem oferecido à mulher maior ingresso no mercado de trabalho e tem proporcionado melhoras de suas condições de vida e oportunidades para questionar esteriótipos relacionados ao gênero.

\section{O debate sobre o fim da teoria}

A ascensão do feminismo circunscreve-se ao fenômeno mais amplo da afirmação da pluralidade das Relaçóes Internacionais (DUNE; HANSEN; WIGHT, 2013), uma vez que é mais uma família teórica - ou seja, um grupo de teorias que, embora apresentem variaçôes, podem ser identificadas como pertencentes a uma categoria específica - que se acrescenta ao estudo das Relaçóes Internacionais. Esse processo de afirmação da pluralidade das Relaçôes Internacionais, verificado com a emergência contínua de novas teorias, tem a vantagem de oferecer a diferentes perspectivas o acesso ao debate teórico da disciplina. Uma desvantagem desse processo, contudo, é o perigo de que cada família teórica se especialize de tal maneira e construa seu arcabouço em premissas tão próprias que as teorias não consigam dialogar entre si. Dessa forma, em vez de teorias, elas virariam espécies de credos religiosos, sobre os quais não há debate, apenas aceitação. Isso impede, por exemplo, analisar as teorias como mais ou menos adequadas para determinadas circunstâncias, passando-se a identificar as teorias como "verdadeiras" ou "falsas".

Por essa razão, tem havido questionamentos sobre qual o fim (objetivo) da teoria, bem como sobre se ela chegou ao fim (término) (GUZZINI, 2013b; REUS-SMIT, 2013). Segundo Lake (2013), a "guerra entre paradigmas" afastou as teorias de seu objetivo precípuo, qual seja: a explicação da realidade. Dune, Hansen e Wight (2013) lembram, contudo, que não necessariamente o objetivo da teoria é explicar a realidade. De toda forma, para Lake (2013), as teorias das Relaçôes Internacionais ganharam características de dogma religioso, incontestáveis e absolutas, o que é traduzido pela ideia de choque entre incomensuráveis. A alternativa a esse impasse é, para Lake (2013), o recurso às teorias de médio alcance, caracterizadas pelo ecletismo analítico. Desse modo, utilizando o que "funciona" nas diferentes famílias teóricas, as teorias de médio alcance propóem-se a resolver problemas específicos das relaçôes internacionais. Lake (2013), então, celebra o fim (término) da teoria - entendida como os Grandes Debates - e defende que os paradigmas devem desenvolver-se inter- 
namente, em vez de disputarem entre si a verdade universal.

Guzzini (2013b) apresenta uma perspectiva diferente da oferecida por Lake (2013), informando que o Debate Interparadigmático não necessariamente resulta na lógica de choque entre incomensuráveis, mas que pode ter por consequência a análise aprofundada dos paradigmas, bem como o aperfeiçoamento dos seus fundamentos. Reus-Smit (2013) também faz ressalva ao argumento de Lake (2013), afirmando que as atuais propostas de ecletismo analítico, ao defenderem a desconsideração da discussão metateórica (teorias sobre a produção de teorias), ignoram que qualquer trabalho, mesmo os empíricos, é informado por metateorias. Por esse motivo, essas propostas não são tão plurais quanto dizem, mas limitadas ontológica e epistemologicamente. Reus-Smit (2013), no entanto, não defende o abandono do ecletismo analítico. Ao contrário, para ele, o que falta é uma versão realmente eclética.

Dune, Hansen e Wight (2013), a seu turno, afirmam que se verificam duas principais correntes sobre o fim (término) da teoria. De um lado, os que defendem a pluralidade sob um único método, de modo que pode haver diversas teorias, desde que elas compartilhem o mesmo conjunto de bases metodológicas, no interior das quais as disputas teóricas podem ocorrer. De outro lado, há o "pluralismo desengajado", para o qual todo tipo de produção teórica é igualmente válida. Para Dune, Hansen e Wight (2013), nenhuma dessas correntes extremas e opostas constitue uma boa opção científica. Propóem, então, o "pluralismo integrativo", que não é nem uma síntese teórica, pois admite a pluralidade das teorias; nem uma teoria de médio alcance, pois recorre a consideraçôes metateóricas. Independentemente da classificação, Dune, Hansen e Wight (2013) debatem acerca de como qualificar a pluralidade, e não se a pluralidade existe. Assim, reconhecem, da mesma forma que este trabalho, a manifestação do fenômeno da pluralidade na disciplina Teoria das Relaçôes Internacionais.

Brown (2013) oferece outra análise sobre o fim (término) das teorias. Afirma que o objetivo de produzir uma Grande Teoria náo deve ser abandonado, mas encorajado, uma vez que a disciplina Relações Internacionais tem sido consumidora, e não produtora de Grandes Teorias, das quais são exemplos as produzidas por Kant e por Hobbes. Brown (2013) informa que os maiores avanços teóricos na disciplina têm sido observados no realismo e no liberalismo. Todavia, ainda há muitos problemas não solucionados pelas "teorias solucionadoras de problemas" - tradução literal para problem-solving theories, categoria analítica desenvolvida por Cox (1983). Brown (2013), dessa forma, sugere uma "teoria crítica solucionadora de problemas", que seria orientada à soluçâo dos problemas, mas que náo tomaria as definiçóes e a realidade como dadas.

\section{Da narrativa às narrativas}

A parte precedente do artigo demonstrou que diversas teorias foram acrescentadas ao conjunto analítico das Relaçôes Internacionais, em um processo contínuo (que se prolonga desde o estabelecimento dos estudos das Relaçôes Internacionais) e ascendente (com a produçấo cada vez maior de teorias). Dessa forma, a afirmação de que a disciplina Relaçóes Internacionais se tornou mais plural (GUZZINI, 2013b; REUS-SMIT, 2013; WAEVER, 1997) parece incontestável. Uma análise mais detida sobre a natureza dessa pluralidade, no entanto, revela que a resposta pode variar conforme a maneira de se aferir a pluralidade.

Quanto à pluralidade absoluta - resultante do processo de aumento da quantidade, segundo os parâmetros apresentados na introdução -, há pouco o que se questionar. Afinal, a quantidade de perió- 
dicos e de cursos de Relaçóes Internacionais cresceu significativamente ao redor do mundo. Nesse sentido, a tabela 1 apresenta dados coletados por Kristensen (2012), que, analisando informaçóes concernentes às Relaçôes Internacionais no banco de dados Web of Science, registra uma evolução do número de periódicos de 36 para 72 e do número de artigos de 2.774 para 4.535, entre 1980 e 2010. $\mathrm{O}$ número crescente de filiados à rede de estudos das Relações Internacionais, International Studies Association (ISA), que passou de 1.963 para 7.011 associados, entre 1963 e 2016 (tabela 2), é outro indicador que confirma a pluralidade absoluta da disciplina, já que evidencia a expansão da comunidade epistêmica na área.

Tabela 1 - Número de periódicos e de artigos em RI (1980-2010)

\begin{tabular}{|c|c|c|}
\hline & Periódicos em Ri & Artigos em RI \\
\hline 1980 & 36 & 2.774 \\
\hline 2010 & 72 & 4.535 \\
\hline
\end{tabular}

Fonte: Elaborada pelo autor com dados extraídos de Kristensen (2012).

Tabela 2 - Número de filiados(as) ò̀ ISA (1963-2016)

\begin{tabular}{|l|c|}
\hline & Filiados à ISA \\
\hline 1963 & 1.963 \\
\hline 1973 & 1.900 \\
\hline 1980 & 2.400 \\
\hline 1994 & 2.621 \\
\hline 2003 & 3.015 \\
\hline 2016 & 7.011 \\
\hline
\end{tabular}

Fonte: Elaborada pelo autor com dados extraídos de ISA (2016).

Essa mesma conclusão de afirmação da pluralidade absoluta é obtida quando se analisam dados específicos do Brasil e da China, por exemplo. Em relação ao Brasil, a evolução numérica na área é evidenciada pelo aumento contínuo da quantidade de cursos de graduaçáo de Relações Internacionais (gráfico 1), bem como pelo aumento da quantidade de alunos e de programas de pós-gra- duação na área de Ciência Política e Relaçóes Internacionais (tabela 3).

\section{Grófico 1 - Evolução da oferta de cursos de RI no Brasil (1970-2010)}

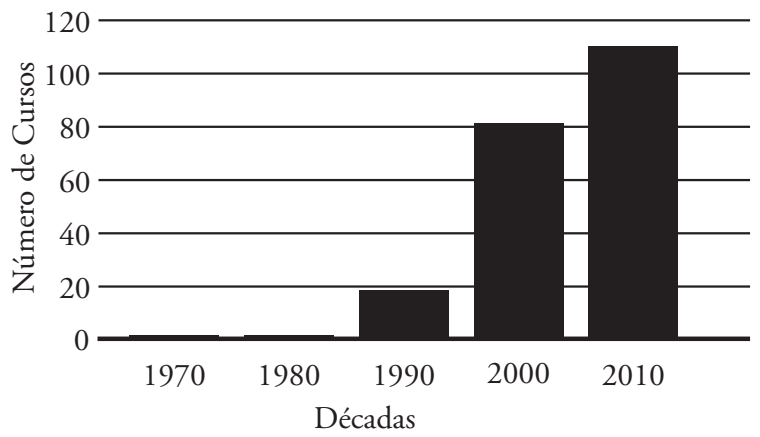

Fonte: Elaborado pelo autor com dados extraídos de Ribeiro, Kato e Rainer (2013).

Tabela 3 - Número de programas na órea de Ciência Política e Relações Internacionais no Brasil (2004-2012)

\begin{tabular}{c|c|c|c|c}
\hline & $\begin{array}{c}\text { Programas } \\
\text { M }\end{array}$ & $\begin{array}{c}\text { Programas } \\
\text { M/D }\end{array}$ & $\begin{array}{c}\text { alunos } \\
\text { ME }\end{array}$ & $\begin{array}{c}\text { alunos } \\
\text { DO }\end{array}$ \\
\hline 2004 & 13 & 6 & 511 & 237 \\
\hline 2007 & 15 & 9 & 442 & 340 \\
\hline 2010 & 26 & 13 & 698 & 469 \\
\hline 2012 & 33 & 17 & 829 & 624 \\
\hline
\end{tabular}

Fonte: Elaborada pelo autor com dados de CAPES (2013). Legenda: $M=$ Mestrado Acadêmico e Profissional; $M E=$ Mestrado Acadêmico; $\mathrm{M} / \mathrm{D}$ = Mestrado e Doutorado; $\mathrm{DO}=$ Doutorado.

No caso chinês, o fenômeno da afirmação da pluralidade absoluta é confirmado por Qin (2010), que demonstra a evolução numérica da quantidade de artigos sobre Relaçóes Internacionais e sobre Teoria de Relaçôes Internacionais em dois importantes periódicos chineses, nomeadamente World Economics and Politics e European Studies. Somando-se a produção dos dois periódicos nessas áreas, tem-se uma evolução de 20 para 209 artigos, entre 1990 e 2004 (tabela 4). No ano de 2003, esse número foi ainda maior: 244 artigos.

O conjunto de todos esses dados permite afirmar que o fenômeno da pluralidade absoluta se verifica. Esse fenômeno, entretanto, não foi acompanhado pela afirmaçáo da pluralidade relativa resultante do processo de aumento da diversidade, 
segundo os parâmetros apresentados na introdução -, como se passa a demonstrar.

Tabela 4 - Publicações sobre RI e TRI em periódicos chineses específicos (1990-2004)

\begin{tabular}{c|c|c}
\hline & $\begin{array}{c}\text { World Economics } \\
\text { and Politics }\end{array}$ & $\begin{array}{c}\text { European } \\
\text { Studies }\end{array}$ \\
\hline 1990 & 20 & 0 \\
\hline 1993 & 27 & 13 \\
\hline 1996 & 35 & 33 \\
\hline 1999 & 77 & 53 \\
\hline 2002 & 154 & 65 \\
\hline 2003 & 181 & 63 \\
\hline 2004 & 147 & 62 \\
\hline
\end{tabular}

Fonte: Elaborada pelo autor com dados extraídos de Qin (2010).

Uma distribuiçấo mais equitativa entre as línguas (inglês, francês, português, espanhol, mandarim, por exemplo) nos periódicos científicos seria um fator coerente com a ideia de pluralidade relativa. Dados da Unesco (2010) apresentados por Tickner (2013a), no entanto, apontam que, em 2010, 80\% dos periódicos acadêmicos referenciados nas Ciências Sociais foram editados em inglês. Outra maneira pela qual a pluralidade relativa poderia manifestar-se seria por uma distribuição mais equitativa entre as nacionalidades na literatura - por exemplo, caso a produçấo acadêmica latino-americana e a africana fossem proporcionais à norte-americana ou à da Europa Ocidental. Dados coletados por Keim (2008), entretanto, apresentam uma forte concentração da literatura de Ciências Sociais. Nesse sentido, os autores e coautores dos Estados Unidos e da Europa Ocidental correspondem, conjuntamente, a $83 \%$ e a $78 \%$ de todos os artigos indexados, respectivamente, no Social Sciences Citation Index e no FRANCIS, enquanto a proporçấo conjunta referente aos autores e coautores da América Latina e da África correspondem a menos de $2,5 \%$ e a $3,3 \%$ nesses dois bancos de dados, respectivamente (tabela 5). Embora esses valores refiram-se às Ciências Sociais como um todo, é pos- sível depreender que, especificamente nas Relações Internacionais, essa realidade não seja tão diferente. Tabela 5 - Artigos em Ciênciass Sociais
segundo a nacionalidade dos autores
e dos coautores

\begin{tabular}{c|c|c}
\hline & $\begin{array}{c}\text { Social Sciences } \\
\text { Citation Index } \\
\text { (Thomson Reuters/ } \\
\text { Estados Unidos) }\end{array}$ & $\begin{array}{c}\text { FRANCIS (Insti- } \\
\text { tut de l'Informa- } \\
\text { tion scientifique et } \\
\text { technique/França) }\end{array}$ \\
\hline $\begin{array}{c}\text { Estados } \\
\text { Unidos }\end{array}$ & $58 \%$ & $44 \%$ \\
\hline $\begin{array}{c}\text { Europa } \\
\text { Ocidental }\end{array}$ & $25 \%$ & $34 \%$ \\
\hline $\begin{array}{c}\text { América } \\
\text { Latina }\end{array}$ & $1 \%$ & $2,3 \%$ \\
\hline África & menos de 1\% & $1,5 \%$ \\
\hline
\end{tabular}

Fonte: Elaborada pelo autor com dados extraídos de Keim (2008).

O reconhecimento científico quanto à influência dos periódicos nas Relaçôes Internacionais também depóe contra a ideia de pluralidade relativa. Em um cenário em que a pluralidade relativa fosse verificada, os periódicos considerados influentes apresentariam nacionalidades diversas, de modo a espelhar proporcionalmente as diferentes formaçôes culturais das nações. Isso, entretanto, não é o que se verifica na pesquisa TRIP around the world: teaching, research, and policy views of International Relations Faculty in 20 countries, conduzida por Maliniak, Peterson e Tierney (2012). Em consulta a 7.001 acadêmicos (dos quais apenas 3.466 responderam) de 20 países, os dez períodos mais influentes na área das Relaçôes Internacionais foram todos norte-americanos (70\%) ou europeus (30\%), conforme se verifica no quadro 1 .

A pluralidade relativa, ou sua ausência, também pode ser aferida por meio da análise do currículo dos cursos de relaçóes internacionais. $\mathrm{O}$ fenômeno da pluralidade relativa seria verificado se a literatura nesses currículos ou a estrutura desses cursos apresentassem uma distribuição equilibrada de nacionalidades ou uma preponderância da literatura local. Assim, para se afirmar que há pluralidade 
Quadro 1 - Periódicos mais influentes nas RI

\begin{tabular}{|c|c|c|}
\hline & Periódico & Editora \\
\hline 1 & International Organization & Cambridge University Press (Reino Unido) \\
\hline 2 & International Studies Quartely & $\begin{array}{c}\text { Wiley-Blackwell, em nome de International Studies } \\
\text { Association (Estados Unidos) }\end{array}$ \\
\hline 3 & International Security & MIT Press (Estados Unidos) \\
\hline 4 & Foreign Affairs & Council in Foreign Relations (Estados Unidos) \\
\hline 5 & American Political Science Review & $\begin{array}{c}\text { Cambridge University Press, em nome da American } \\
\text { Political Science Association (Estados Unidos) }\end{array}$ \\
\hline 6 & World Politics & $\begin{array}{c}\text { Cambridge University Press, em nome do Princeton } \\
\text { Institute for International and Regional Affairs (Estados } \\
\text { Unidos) }\end{array}$ \\
\hline 8 & European Journal of International Relations & $\begin{array}{c}\text { Sage Publications, em nome da University of Maryland } \\
\text { (Estados Unidos) }\end{array}$ \\
\hline 9 & Journal of Conflict Resolution & $\begin{array}{c}\text { Sage Publications, em nome da University of Maryland } \\
\text { (Estados Unidos) }\end{array}$ \\
\hline 10 & Foreign Policy & FP Group (Estados Unidos) \\
\hline
\end{tabular}

Fonte: Elaborado pelo autor com dados extraídos de Maliniak, Peterson e Tierney (2012).

relativa, seria necessário que cursos de Relações Internacionais na América Latina, por exemplo, apresentassem uma distribuição mais equitativa em termos da nacionalidade da literatura utilizada ou que a origem latino-americana fosse mais presente nessa literatura. Essa distribuição equitativa demonstraria que o estudo das Relaçóes Internacionais recebe influência das diferentes formaçôes culturais e se desenvolve em diferentes locais do mundo, não sendo dominado por alguma tradição específica. A prevalência da literatura local demonstraria que o estudo das Relaçóes Internacionais náo se esquiva à análise crítica da relação entre teorias, problemas e contextos "universais" e teorias, problemas e contextos "locais". Nenhum desses cenários (distribuição equitativa ou predomínio da literatura local) é o que se verifica na Coreia do Sul, por exemplo, onde $63,6 \%$ da literatura relativa às Relações Internacionais utilizada no país são norte-americanas (traduzidas ou transcritas diretamente), conforme apontam Moon e Kim (2002). Também não é o que ocorre na Nigéria, onde a grade curricular mínima obrigatória determinada pela Comissão Universitá- ria Nacional para os programas de graduação em Relaçôes Internacionais é composta por 45 disciplinas, das quais apenas $6(13,3 \%)$ são voltadas aos estudos africanos, enquanto as outras $39(86,7 \%)$ são dedicadas à escola de pensamento eurocêntrico (FALEYE, 2014). É bastante plausível crer que esse cenário não é uma particularidade desses dois países, mas uma realidade em diversos outros.

Desse modo, conclui-se que, embora a pluralidade absoluta tenha se manifestado na disciplina, a pluralidade relativa ainda é um fenômeno que enfrenta muitos desafios para se afirmar. Nesse sentido, a pluralidade absoluta na área de Relaçóes Internacionais é demonstrada pelo número crescente de periódicos, de estudantes, de cursos de graduação e de programas de pós-graduação. Os desafios à pluralidade relativa, por sua vez, são postos pela concentração da língua inglesa nos períodos, pela muito baixa representatividade de autores e coautores africanos e latino-americanos na literatura de Ciências Sociais, pela origem extremamente limitada (norte-americana e europeia apenas) dos periódicos considerados mais influentes nas Relaçôes 
Internacionais pela comunidade acadêmica e pela significativa predominância da literatura norte-americana ou europeia nos cursos de Relaçóes Internacionais nos países.

Esse estado de coisas - consolidação apenas da pluralidade absoluta nas Relaçôes Internacionais - tem sido identificado e combatido pela comunidade científica. A narrativa tradicional, exposta na primeira parte, tem sido criticada. Novas alternativas teóricas e novas formas de analisar as Relações Internacionais têm sido formuladas, ao que se dedica esta parte do artigo a partir de entáo.

\section{Críticas à narrativa tradicional}

A primeira crítica à narrativa tradicional das Relaçóes Internacionais é que, ironicamente, a disciplina não é internacional. De acordo com Tickner e Waever (2009), desde Hoffmann (1977), fala-se que as Relações Internacionais são uma disciplina norte-americana. Uma versão um pouco menos restritiva dessa afirmação refere-se às Relações Internacionais como uma disciplina ocidental, em vez de norte-americana apenas (ACHARYA; BUZAN, 2010). Por essa razão, Tickner (2013a) afirma que há uma divisão quase intransponível entre "periferia" e "centro" do conhecimento teórico da disciplina. Os dados apresentados quanto à predominância da língua inglesa (UNESCO, 2010 apud Tickner, 2013a) e quanto à nacionalidade dos autores e dos coautores nas Ciências Sociais (tabela 5) apontam para a confirmaçáo do argumento de Tickner e Waever (2009), de Acharya e Buzan (2010) e de Tickner (2013a).

Uma segunda crítica associa-se não apenas ao lugar de produção do conhecimento, mas também aos critérios para o reconhecimento da validade científica do conhecimento. Nesse sentido, Tickner e Waever (2009) elaboram o conceito de epistemologia geocultural ${ }^{10}$, para se referirem ao fato de que

10. É possível identificar pontos de contatos entre os conceitos de epistemologia geocultural, de Tickner e Waever (2009), e de a forma da produção e o que é produzido nas Relaçôes Internacionais também seguem cânones estabelecidos pelos Estados Unidos. Os dados apresentados quanto à origem dos periódicos reconhecidos como os mais influentes (quadro 1) nas Relações Internacionais sugerem a confirmação desse argumento de Tickner e Waever (2009).

Para Acharya e Buzan (2010), a dominação na Teoria das Relaçôes Internacionais manifestase de duas maneiras. Primeiramente, pelo próprio embasamento teórico da Teoria das Relações Internacionais advém da filosofia, da teoria política e da história ocidentais. Igualmente, pelo modo eurocêntrico de enquadrar e de contar a história mundial, que ajuda a moldar a Teoria das Relaçóes Internacionais. Os dados apresentados quanto à origem da literatura adotada nos cursos de Relaçôes Internacionais na Coreia do Sul (MOON; KIM, 2002), bem como quanto à grade curricular obrigatória mínima dos cursos de graduação de Relaçóes Internacionais na Nigéria (FALEYE, 2014) indicam a pertinência da crítica de Acharya e Buzan (2010).

\section{Em busca de novas alternativas}

Diante desse contexto de concentração do conhecimento teórico nas Relações Internacionais, começa-se a analisar o fenômeno pelo lado inverso. Em outros termos, ao invés de se estudar como o centro se apresenta por meio das produçóes intelectuais, passa-se a analisar como a periferia tem tentado apresentar produçôes teóricas alternativas àquelas produzidas pelo centro.

Essa tarefa, no entanto, não pode ser realizada de maneira táo direta. Afinal, ao tentar entender como se configura a Teoria de Relaçóes Internacionais ao redor do mundo, uma questão se faz premente: que conhecimento procurar

epistemologias do Sul, de Boaventura de Sousa Santos (1995), já que ambos denunciam a dominaçáo epistemológica, que leva "à supressão de muitas formas de saber próprias" (MENESES; SANTOS, 2009, p. 13). 
(TICKNER; WAEVER, 2009)? Há a consciência de que a busca de produção nacional pode ser condicionada pelas lentes da Teoria das Relaçóes Internacionais desenvolvida pelo centro. Em consequência, para pensar na disciplina "além do Ocidente" (ACHARYA; BUZAN, 2010), é necessário "pensar as Relações Internacionais diferentemente" (BLANEY; TICKNER, 2012) ou seja, reinterpretar elementos analíticos (como Estado e segurança) que fundamentam a Teoria das Relações Internacionais desenvolvida pelo centro, bem como introduzir elementos analíticos (como religiáo e ética) não incorporados aos modelos teóricos do centro.

Desse modo, passa-se a refletir sobre a cientificidade das Relaçôes Internacionais. Esse movimento é necessário, pois diversos modos de pensar a disciplina pela periferia são rejeitados pelo centro sob a justificativa de não serem científicos, mas ideológicos (BLANEY; TICKNER, 2012). Isso aconteceu, por exemplo, com a Teoria da Dependência, latino-americana, que foi recebida pelaacademia norte-americanacomoempiricamente inadequada ou como invariavelmente política (BLANEY; INAYATULLAH, 2008; CORDOSO, 1977 apud BLANEY; TICKNER, 2012), e aconteceu também com teorias africanas sobre subdesenvolvimento (BLANEY; TICKNER, 2012).

Nesse sentido, para pensar as Relaçóes Internacionais diferentemente (reinterpretar elementos tradicionais e introduzir novos elementos nos modelos teóricos), Blane e Tickner (2013) recomendam um duplo processo: desaprender e reaprender (tradução livre para de-schooling e re-schooling, respectivamente). Desaprender implica a desconstrução das supostas identidades universais, que, por meio desse recurso, se revelam identidades locais. Reaprender, por sua vez, refere-se ao processo de construção de Teorias das Relaçóes Internacionais por meio de tradiçôes de pensamento negligenciadas ou desprezadas - seria o caso, por exemplo, de adotar, com maior expressividade, a escola de pensamento africano nas Relaçóes Internacionais na Nigéria, revertendo o cenário apresentado por Faleye (2014), de prevalência da escola de pensamento eurocêntrico na grade curricular obrigatória mínima dos cursos de graduação de Relaçóes Internacionais nigerianos.

\section{Algumas estratégias}

Depois de ter apresentado a crítica à narrativa tradicional das Relaçóes Internacionais, bem como de ter introduzido o quadro geral da busca por produçôes teóricas alternativas àquelas produzidas pelo centro, passa-se a analisar algumas estratégias específicas de formulação dessas novas produções teórica.

Neumann (2013) propõe uma análise do período de formação dos Estados, para se perceber como se formataram as Relações Internacionais. Acharya e Buzan (2010), a seu turno, analisando a produção autônoma de Teorias das Relações Internacionais na Ásia, informam que quatro estratégias têm sido adotadas por acadêmicos do continente. Primeira, a utilização de tradiçóes clássicas asiáticas - militares, políticas e religiosas, a exemplo de Sun Tzu, Confúcio e Kautilia, respectivamente. Segunda, o recurso ao pensamento e à atuação externa de líderes asiáticos, como Nehru, Mao e Sukarno. Terceira, a adaptação da Teoria das Relações Internacionais às características asiáticas. Quarta, o desenvolvimento de conceitos próprios como ferramentas de análise do sistema internacional.

$\mathrm{Na}$ Índia, por exemplo, Behera (2010), informa que se tem recorrido às tradiçôes clássicas (como a noção hindu de irmandade no lugar de Estado, o que implicaria um modelo diferente das teorias de Relaçôes Internacionais baseadas no Estado-nação vestfaliano) e aos pensadores do país (como Kautilia), bem como à atuação externa de 
líderes nacionais (como Ghandi e Nehru). Isso, todavia, impõe outros desafios. Conceitos como Estado-nação e nacionalismo, que fundamentam a teoria tradicional das Relações Internacionais, são questionados pelo pensamento clássico indiano. Ilustrativamente, Sri Aurobindo Ghosh percebia a naçáo indiana de maneira menos territorializada e mais espiritualizada (BEHERA, 2010). Igualmente, Gandhi diferenciava, sensivelmente, uma nação genuína (comunidade) de um agrupamento de pessoas mantidas unidas pela força da Administração (BEHERA, 2010). Esses dois exemplos ilustram a dificuldade (ou mesmo impossibilidade) de se produzir uma Teoria das Relações Internacionais indiana sem que sejam redefinidos os conceitos tradicionais da disciplina.

\section{(RE)INTRODUZINDO O ELEMENTO ÉTICA}

No mundo islâmico, também se verifica essa dificuldade/impossibilidade de se desenvolver uma Teoria de Relações Internacionais própria, valendose dos conceitos tradicionais do centro, estranhos à cultura local (TADJAKHSH, 2010).

Particularmente, há incompatibilidade entre a razâo do Estado e a razão do Islá. Nesse sentido, a secularização e o projeto liberal de modernização confrontariam a identidade islâmica, que é baseada na religião, na fé e na moralidade (TADJAKHSH, 2010). Essa diferença entre fundamentos filosóficos e teleológicos impediria, segundo Tadjakhsh (2010), que se constatasse a existência de uma Teoria das Relaçôes Internacionais islâmica.

Dessa forma, Tadjakhsh (2010) chama atenção para a teoria islâmica de Relaçôes Internacionais, que seria derivada de várias fontes relacionadas ao Profeta, como o Corão, a Xaria, a Suna, os Hádices. Isso põe em destaque duas conclusões. Primeira, a grande divergência com as clássicas fontes da Teoria das Relaçôes Internacionais ocidental. Segunda, o caráter normativo da Teoria das Relações Internacionais islâmica. Para esta, por exemplo, a adoçâo da justiça e da moralidade ética leva à paz e à ordem nas relações no mundo islâmico. A relação causal é a inversa para os realistas, que percebem a justiça como um subproduto da ordem.

A questão da ética como padrão de relacionamento é também suscitada por Chekuri (2013), que se utiliza de crônicas do século XVII sobre o reino de Tanjavur, localizado no sul da atual Índia. O objetivo do autor é demonstrar que existem outras lógicas de socialização, além da liberal, que identifica no egoísmo e no interesse pessoal a principal característica das relaçóes humanas. Segundo essas crônicas, em nome de ideais éticos, Visvanãtha Nãsyaka luta contra o próprio pai, que percebe o reino de Tanjavur como sua propriedade. Embora o pai tente convencer seu filho a evitar a luta, lembrando-lhe que ele é o sucessor no reinado, Visvanãtha segue sua batalha, movido por princípios e por desprendimento de poder. $\mathrm{O}$ imperador, em reconhecimento a Visvanátha, premia-o com outro reinado. Assim, estabelece-se um governo de pessoas elevadas, desprendidas de poder e motivadas por valores éticos.

Esses dois exemplos ilustram que uma das formas de se pensar as Relaçôes Internacionais diferentemente é introduzir o componente ético no modelo de análise. Esse pleito, no entanto, não está restrito a autores orientais. No próprio Ocidente, verificam-se movimentos nesse sentido. Smith (2004), por exemplo, informa que não existe ciência social que não seja normativa, desprovida de valor. Para ele, então, é falso o princípio da neutralidade científica, que, supostamente, embasa a construção da Teoria das Relaçôes Internacionais. Além disso, mesmo que existisse, o princípio da ciência não normativa não seria desejado, pois sua adoçâo impediria que as relações internacionais fossem pautadas por garantias éticas que se pretendem conferir aos indivíduos. Justificando, Smith (2004) informa que esse modelo ilusório de ciência não 
normativa impede que a sociedade internacional se responsabilize pelos problemas que afetam as outras naçôes. Assim, enquanto as atuais premissas da Teoria das Relaçóes Internacionais tradicional percebem a violência como combate militar apenas, Smith (2004) lembra que a forma mais veemente de violência é a econômica, que se manifesta, por exemplo, na fome.

\section{O MODELO TAOÍSTA}

É possível vislumbrar-se, também, uma tentativa de se estabelecer uma Escola Chinesa de Teoria das Relaçóes Internacionais, que também advoga a superação da ordem vestfaliana. Para Ling (2014), a lógica vestfaliana de relaçôes entre Estados incorre em dois grandes problemas. O primeiro é o que Hobson (2012) chama de "teoria do Big Bang eurocêntrico da política mundial", que pressupõe a inexistência de quaisquer outras formulações teóricas anteriores à ocidental. O segundo problema é o padráo de relacionamento conflitivo que decorre do Estado vestfaliano, que é racional e territorial e cujo objetivo é a sobrevivência. Ling (2014), nesse sentido, propõe um modelo de Relaçóes Internacionais baseado no taoísmo, que tem origem milenar - ou seja, bem anterior à ordem vestifaliana, contrariando a "teoria do Big Bang eurocêntrico da política mundial" (HOBSON, 2012).

No taoísmo, yin e yang são opostos, mas complementares. Assim, o yin só existe pela existência do yang, e vice-versa. Igualmente, o yin, por trazer em sua essência o yang, neste se transforma, e vice-versa. Dessa forma, pela influência, pela necessidade e pela transformação recíprocas, não há relação hierárquica entre esses polos, que são identificados como complementares. A aplicação dessa lógica às relaçóes internacionais leva à emergência do que Ling (2014) chama de mundismo/mundialismo (tradução literal de worldism), que reconhece a intersubjetividade dos Múltiplos Mundos. Isso implica que, enquanto, na ordem vestfaliana, os
Estados se inserem em um sistema competitivo, e o meio de atuação internacional é o power politics; na ordem do worldism, os Estados se inserem em um sistema que admite a possibilidade de existirem várias formas de interação, e o meio de atuação internacional é a dialética taoísta (que reconhece a mútua contradição e complementaridade entre os polos opostos). Coerente com a ideia dialética taoísta, Ling (2014) não propõe a ordem mundistal mundialista como substituta da ordem vestfaliana. Propóe, sim, a coexistência e a interação entre esses polos, que representariam o yin e o yang do tao - ou seja, seriam contraditórios, mas complementares.

\section{Conclusão}

A questão da pluralidade da disciplina das Relaçóes Internacionais apresenta duas respostas, a depender dos critérios adotados para se definir pluralidade.

A primeira resposta deriva da análise do fenômeno segundo as lentes da pluralidade absoluta. Sob essa perspectiva, pode-se afirmar que a disciplina Relaçôes Internacionais se tornou mais plural. Afinal, verificam-se notável crescimento na quantidade de teorias (ainda que inspiradas por matizes tradicionais), como demonstrou a primeira parte do artigo; e significativo crescimento de periódicos e de artigos especializados (tabela 1, tabela 4), de filiados à ISA (tabela 2) e de cursos de graduaçấo e de programas pós-graduação (gráfico 1, tabela 3). Embora alguns desses dados refiram-se a contextos específicos (como periódicos registrados no Web of Science, cursos no Brasil, filiados à ISA, artigos em periódicos chineses), é possível depreender que esse fenômeno de expansão (de cursos, de periódicos, de artigos, de filiados a associaçôes) se verifica em contextos não explicitados pelos dados trazidos por este artigo. Assim, esse fenômeno de expansão seria a característica geral na área das Relaçōes Internacionais. 
A segunda resposta decorre da análise do fenômeno segundo as lentes da pluralidade relativa. Sob essa lente, o acréscimo vertiginoso na quantidade náo tem sido, nem de longe, acompanhado pelo incremento na diversidade. Dessa forma, embora o número de cursos e de periódicos tenha aumentado, onde, o que e como se ensinam as Relaçôes Internacionais continua concentrado, repetido, limitado. Como exemplo, pode-se afirmar que ainda predominam a língua inglesa nos periódicos das Ciências Sociais (UNESCO, 2010 apud TICKNER, 2013a); a expressiva desproporção entre a quantidade de artigos em Ciências Sociais oriundos dos Estados Unidos e da Europa Ocidental (mais de 75\%, conforme tabela 5), em relação aos produzidos na América Latina e na África (no máximo, $3,3 \%$, conforme tabela 5); as grades curriculares com grande participaçáo da literatura norte-americana e do pensamento eurocêntrico, independentemente do local onde esses cursos sejam ministrados, como sugere a comparaçáo entre o estudo das Relações Internacionais na Nigéria (FALEYE, 2014) e na Coreia do Sul (MOON; KIM, 2002); os critérios tradicionais para a identificação e para a legitimação do conhecimento científico, que levaram ao reconhecimento apenas de periódicos norte-americanos (7) e europeus (3) entre os 10 periódicos mais influentes no mundo, na área das Relaçôes Internacionais (MALINIAK; PETERSON; TIERNEY, 2012). Por esses motivos, entre outros, é possível argumentar que o fenômeno da pluralidade relativa ainda encontra muitas dificuldade para se afirmar.

Tem-se visto, no entanto, a emergência de vários movimentos que advogam a ampliação do referencial teórico da disciplina Relaçôes Internacionais. Dessa forma, fala-se em Relaçóes Internacionais "além do Ocidente" (ACHARYA; BUZAN, 2010) ou mesmo "pós-Ocidente" (ACHARYA, 2014). Esses movimentos fazem parte, segundo Acharya (2014), de um contexto ainda mais amplo que pretende criar as Relações Internacionais Globais. Dessa forma, a dicotomia excludente entre Ocidente e Oriente seria afastada, permitindo-se uma disciplina que contemplasse ambas as perspectivas simultaneamente. $\mathrm{O}$ objetivo seria evitar tanto o paroquialismo (que desconsidera os fatores externos e os contextos mais amplos, voltando-se apenas para a realidade local, considerada como universal) quanto o essencialismo (que pressupóe a inexistência de quaisquer outras formulações teóricas anteriores à ocidental). O resultado, então, é a emergência do mundo multiplexo - tradução literal para multiplex world (ACHARYA, 2014). No mundo multiplexo, múltiplos atores são reconhecidos como legítimos, atores esses que se relacionam por meio de interações complexas de interdependência.

Assim, verifica-se a emergência de teorias próprias de Relações Internacionais em outros lugares do mundo, notadamente na periferia. Um desafio que se impóe ao reconhecimento dessa emergência é o de que a busca de produção nacional pode estar condicionada pelas lentes da Teoria das Relaçóes Internacionais desenvolvida pelo centro. Por esse motivo, é necessário "pensar as Relaçôes Internacionais diferentemente" (BLANEY; TICKNER, 2012), conferindo novos significados a elementos tradicionais (como a ideia de Estadonação) das teorias das Relaçóes Internacionais desenvolvidas pelos centro; bem como introduzindo novos elementos (como a religiáo) nos modelos teóricos dos estudos das Relaçôes Internacionais.

Diversas são as maneiras que têm sido utilizadas para se pensar as Relaçôes Internacionais diferentemente. Acharya e Buzan (2010) citam a utilização de tradições clássicas locais, o recurso ao pensamento e à atuação externa de líderes políticos, a adaptação da Teoria das Relaçóes Internacionais do centro às características locais, e a elaboração de conceitos e seu desenvolvimento em teorias. 
Tadjakhsh (2010) menciona a utilização do Corão. Chekuri (2013) recorre a relatos históricos em formato de crônicas. Ling (2014) propóe um modelo de relações internacionais baseado no taoísmo.

Apesar desses esforços, a análise da produção de teorias das Relações Internacionais na periferia revela uma situação complexa. Conforme identificado por Tickner (2013a), embora acadêmicos da periferia afirmem que as teorias do centro não são adequadas para analisar as características do Terceiro Mundo, neste, há pouca produção teórica. Quando essa produção existe, ela é normalmente dominada por questóes práticas de política externa e pela utilização do Estado como unidade de análise. Por esse motivo, Tickner (2013a) fala em (neo)imperialismo das Relaçôes Internacionais, ao analisar a disciplina sob a perspetiva da relação centro-periferia.

Uma das explicações possíveis é apontada por Tickner (2013b, p. 217) e refere-se à própria formação de uma disciplina acadêmica. Esse processo impóe, em certa medida, conformidade e cumplicidade. Afinal, "ser aceito como membro de um campo acadêmico implica o reconhecimento dos valores deste campo, a rejeição de epistemologias diferentes do padrăo, e a afirmação da importância do conhecimento acadêmico, que se opôe ao prático".

Outra explicaçáo pode ser a questão das assimetrias. Nesse sentido, Tickner e Waever (2009) mencionam que há significativas assimetrias nas relações de poder (exemplificada pela imposição da língua inglesa), nas condiçôes de trabalho e nos recursos à disposição dos acadêmicos da periferia. Essas assimetrias contribuem para a dominação do centro sobre a produção do conhecimento de Teoria das Relaçóes Internacionais.

$\mathrm{O}$ argumento do imperialismo, no entanto, deve ser visto com cautela. Por meio desse argumento, normalmente, é estabelecida uma relação binária e maniqueísta, segundo a qual o "astuto" centro se impóe sobre a "inocente" periferia. $\mathrm{O}$ argumento do imperialismo, então, pode representar uma nova forma de contar o mito do bom salvagem, que tem em Rousseau seu principal difusor.

A cautela que é solicitada para analisar o imperialismo não é necessariamente para negar a existência desse fenômeno. Solicita-se cautela, sim, para se reconhecer que a periferia também é responsável por essa relação imperialista - ou seja, a periferia não pode se acomodar no papel do "inocente iludido". Dessa forma, caso se fale em imperialismo na disciplina Relaçôes Internacionais, esse argumento tem de ser acompanhado de outros termos, como, por um lado, aceitação e conveniência; por outro, emancipação e descolonização da disciplina.

Procura-se chamar atençáo para o fato de que, dificilmente, a disciplina Relaçôes Internacionais ganhará pluralidade relativa espontaneamente, por ato de generosidade do centro. Analisando-se essa situação sem paixôes, pode-se constatar que não chega a ser um absurdo que só se reconheça como legítimo aquilo com o que se está acostumado. Para reverter isso, é necessário que outras formas de ver o mesmo fenômeno sejam estabelecidas, defendidas, explicadas e reforçadas. É por essas razóes que a periferia tem um papel fundamental a desempenhar para que a disciplina alcance maior pluralidade relativa.

A concentração do conhecimento na disciplina Relações Internacionais é prejudicial ao próprio desenvolvimento desta, que, em vez de evoluir, se repete. Por esse motivo, são salutares as tentativas de contribuiçóes originais à disciplina, que assumem diversas formas. É possível que se esteja caminhando rumo a uma pluralidade relativa da disciplina, ou, pelo menos, a uma menor concentração. Essa caminhada dependerá enormemente do empenho da periferia, que tem muito a contribuir para a evolução da disciplina. 


\section{Referências}

ABBAGNANO, Nicola. Dicionário de filosofia. 5. ed. São Paulo: Martins Fontes, 2007.

ACHARYA, Amitav; BUZAN, Barry. Why is there no non-western international theory? and introduction. In: ACHARYA, Amitav; BUZAN, Barry (Org.). Non-western international relations theory: perspectives on and beyond Asia. London: Routledge, 2010. p. 1-25.

ACHARYA, Amitav. Global International Relations and regional worlds: a new agenda for international studies. International Studies Quarterly, v. 58, p. 647-659, 2014.

BALDWIN, David (Ed.). Neorealism and neoliberalism: the contemporary debate. New York: Columbia University Press, 1993.

BECHARA, Evanildo. Moderna gramática portuguesa. 37. ed. Rio de Janeiro: Nova Fronteira, 2009.

BEHERA, Navnita Chadha. Re-imagining IR in India. In: ACHARYA, Amitav; BUZAN, Barry (Org.). Non-western international relations theory: perspectives on and beyond Asia, p. 92-116, 2010.

BLANEY, David L.; TICKNER, Arlene B. Introduction: thinking difference. In: BLANEY, David L.; TICKNER, Arlene B. (Ed.). Thinking International Relations Differently. New York and London: Rouledge, 2012.

BLANEY, David L.; TICKNER, Arlene B. Introduction: claiming the international beyond IR. In: BLANEY, David L; TICKNER, Arlene B. (Ed.). Claiming the international: worlding beyond the West series. London and New York: Routledge, p. 1-24, 2013.

BROWN, Chris. The poverty of grand theory. European Journal of International Relations, v. 19, n. 3, p. 483-497, 2013.

CAPES. Relatório de Avaliaçáo Trienal 2013: área de Ciência Política e Relaçôes Internacionais. Disponível em: < https:// www.capes.gov.br/images/stories/download/avaliacaotrienal/ Docs_de_area/CI\%C3\%AAncia_Pol\%C3\%ADtica_doc_ area_e_comiss\%C3\%A3o_21out.pdf>. Acesso em: 06 mai. 2016.

CASTRO, Thales. Teoria das relaçóes internacionais. Brasília: Fundação Alexandre de Gusmão, 2012.

CHEKURI, Chandra. Becoming Nãyaka: sovereignty and ethics inthe Tanjãvuri Ândhra Rãjula Caritra. In: BLANEY, David L.; TICKNER, Arlene B. (Ed.). Claiming the international: worlding beyond the West series. London and New York: Routledge. p. 61-77, 2013.

COX, Robert W. Social forces, states and world order: beyond IR theory. Millennium: Journal of International Politics, v. 10, n. 2, p. 126-155, 1983.

DOYLE, Michael W.; IKENBERRY, G. John. Conclusion: continuity and innovation in international relations theory. In: DOYLE, Michael W.; IKENBERRY, G. John. (Ed.). New thinking in international relations theory. Boulder: Westview. 1997. p. 266-280.

DUNNE, Tim; HANSEN, Lene; WIGHT, Colin. The end of International relations theory? European Journal of International Relations, v. 19, n. 3, p. 405-425, 2013.

FALEYE, Olukayode A. Africa and international relations theory: acquiescence and responses. Journal of Globalization Studies, v. 5, n. 2, p 81-90, 2014.

FINNEMORE, Martha; SIKKINK, Kathryn. Taking stock: the constructivist research program in International Relations and Comparative Politics. Annual Review Political Science, v.4, p.391-416, 2001.

GUZZINI, Stefano. Power, realism and constructivism. London and New York: Routledge, 2013a.

GUZZINI, Stefano. The ends of International Relations theory: stages of reflexivity and modes of theorizing. European Journal of International Relations, v. 19, n. 3, p. 521-541, 2013b.

HOBSON, J. The eurocentric conception of world politics: western international theory, 1760-2010. Cambridge: Cambridge University Press, 2012.

HOFFMANN, Stanley. An American Social Science: International Relations. Daedalus, v. 106, n. 3, p. 41-60, 1977.

ISA. Membership growth over time. Disponível em: <http:// www.isanet.org/ISA/About-ISA/Data/Membership>. Acesso em: 07 mai. 2016.

JACKSON, Patrick Thaddeus; NEXON, Daniel H. Paradigmatic faults in international-relations theory. International Studies Quarterly, v. 53, p. 907-930, 2009.

KAHLER, M. Inventing international relations: international relations theory after 1945. In: DOYLE, Michael W.; IKENBERRY, John. (Ed.). New thinking in international relations theory. Boulder: Westview, 1997. p. 20-53.

KEIM, W. Social sciences internationally: the problem of marginalisation and its consequences for the discipline of sociology. African Sociological Review, n. 12, v. 2, p. 22-48, 2008.

KEOHANE, Robert O. The demand for international regimes. International Organization, v. 36, n. 2, p. 325-355, 1982.

KEOHANE, Robert O. After hegemony. Princeton: Princeton University, 1984.

KEOHANE, Robert O. International institutions: two approaches. International Studies Quarterly, v. 32, n. 4, p. 379-396, 1988.

KEOHANE, Robert O.; MARTIN, Lisa L. The promise of institutionalist theory. International Security, v. 19, n. 1, p. 39-51, 1995.

KEOHANE, Robert O. Beyond dichotomy: conversations between International Relations and feminist theory. International Studies Quarterly, v. 42, n. 1, p. 193-197, 1998a.

KEOHANE, Robert O. International relations: old and new. 
In: GOODIN, R; KLINGEMANN, H. A new handbook of political science. Oxford: Oxford University, 1998b.

KEOHANE, Robert O. Twenty years of institutional liberalism. International Relations, v. 26, n. 2, p. 125-138, 2012.

KRATOCHWIL, Friedrich V. Rules, norms, and decisions: on the conditions of practical and legal reasoning in international relations and domestic affairs. Cambridge: Cambridge University, 1989.

KRISTENSEN, Peter Marcus. A not so American social science: alternative cartographies of International Relations. Copenhagen: University of Copenhagen, 2012.

KURKI, Milja; WIGHT, Colin. International relations and social science. In: DUNNE, Tim; KURKI, Milja; SMITH, Steve. (Ed.). International relations theories: discipline and diversity. 3. ed. Oxford: Oxford University, p. 14-35, 2013.

LAKE, David A. Theory is dead, long live theory: the end of the great debates and the rise of eclecticism in International Relations. European Journal of International Relations, v. 19, n. 3, p. 567-587, 2013.

LAPID, Yosef. The third debate: on the prospects of international theory in post-positivist era. International Studies Quartely, v.33, n. 3, p. 235-254, 1989.

LESSA, Antônio Carlos. O ensino de Relaçôes Internacionais no Brasil. In: SARAIVA, José Flávio Sombra; CERVO, Amado Luiz. (Org.). O crescimento das relaçóes internacionais no Brasil. Brasília: Instituto Brasileiro de Relaçôes Internacionais, p. 33-50, 2005.

LING, L. The Dao of world politics: towards a post-Westiphalian, worldist International Relations. London and New York: Routledge, 2014.

MALINIAK, Daniel; PETERSON, Susan; TIERNEY, Michael. TRIP around the world: teaching, resarch, and policy views of International Relations Faculty in 20 countries. Williamsburg: The College of William and Mary, 2012.

MEARSHEIMER, John. The false promise of international institutions. International Security, v. 19, n. 3, p. 5-49, 1994-1995.

MENESES, Maria Paula; SANTOS, Boaventura de Sousa. (Org.). Epistemologias do sul. Coimbra: Almedina, 2009.

MOON, Chung-in; KIM, Taehwan. International relations studies in South Korea. Journal of East Asian Studies, v. 2, n. 1, p. 45-68, 2002.

NEUMANN, I. Claiming the eraly state for the relational turn: the case of Rus' (ca 800-1100). In: BLANEY, David L.; TICKNER, Arlene B. (Ed.). Claiming the international: worlding beyond the West series. London and New York: Routledge. 2013. p. 78-97.

NOGUEIRA, João Pontes; MESSARI, Nizar. Teoria das relaçóes internacionais. Rio de Janeiro: Elsevier, 2005.

ONUF, Nicholas. Making sense, making worlds: constructivism in social theory and international relations. London and New York: Routledge, 2013.
QIN, Yaqing. Why is there no Chinese international relatins theory? In: ACHARYA, Amitav; BUZAN, Bary. (Org.). Non-Western International Relations theory: perspectives on and beyond Asia, p. 26-50, 2010.

RAMOS, Leonardo César Souza. Some critical reflections on Charles Glaser and the neo-neo synthesis. Estudos Internacionais. v. 1, n. 2, p. 319-328, jul./dez. 2013.

REUS-SMIT, Christian. Beyond metatheory? European Journal of International Relations, v. 19, n. 3, p. 589-608, 2013. RIBEIRO, Pedro Feliú; KATO, Mariama; RAINER, Gary. Mercado de Trabalho e Relaçóes Internacionais no Brasil: um estudo exploratório. Boletim Meridiano 47, v. 14, n. 135, p. 10-18, 2013.

RUGGIE, John Gerard. The false premise of realism. International Security, v. 20, n. 1, p. 62-70, 1995.

SANTOS, Boaventura de Sousa. Toward a new common sense: law, science and politics in the paradigmatic transition. New York: Routledge, 1995.

SMITH, Steve. Singing our world into existence: International Relations theory and September 11. International Studies Quarterly, v. 48, p. 499-515, 2004.

SNYDER, Jack. One world, many theories. Foreign Policy, n. 145, p. 52-62, 2004.

STEANS, Jill. Global governance: a feminist perspective. In: HELD, David; McGREW, Anthony (Ed.). Governing globalization: power, authority and global governance. Oxford: Polity Press, 2002.

TADJAKHSH, Shahrbanou. International Relations theory and the Islamic worldview. In: ACHARYA, Amitav; BUZAN, Bary. (Org.). Non-western international relations theory: perspectives on and beyond Asia. 2010. p. 174-196.

TICKNER, Arlene . You just don't understand: troubled engagements between feminists and IR theory. International Studies Quarterly, v. 41, p. 611-632, 1997.

TICKNER, Arlene B.; WAEVER, Ole. Introduction: geocultural epistemologies. In: TICKNER, Arlene B.; WAEVER, Ole. (Org.). International Relations scholarship around the world. 2009. p. 1-31.

TICKNER, Arlene. Core, periphery and (neo)imperialist International Relations. European Journal of International Relations, v. 19, n. 3, p. 627-646, 2013 a.

TICKNER, Arlene . By the way of conclusion: forget IR? In: BLANEY, David; TICKNER, Arlene. (Ed.). Claiming the international: worlding beyond the West series. London and New York: Routledge. 2013b. p. 214-232.

TICKNER, Jane Ann . Hans Morgenthau's principles of political realism: a feminist reformulation. In: DER DERIAN, James. (Ed.). International theory: critical investigations. New York: New York University Press. 1995. p. 53-71.

UNESCO (ed.). World social science report 2010: knowledge divides. Paris: International Social Science Council, UNESCO, 2010. 
WAEVER, Ole. Figures of international thought: introducing persons instead of paradigms. In: NEUMANN, Iver; WAEVER, Ole. The future of international relations: master in the making? London: Routledge, 1997.

WALT, Stephen M. International relations: one world, many theories. Foreign Policy, n 110, p. 29-32, 34-46, 1998.

WALTZ, Kenneth. Theory of international politics. Reading: Addison-Wesley Pub. Co., 1979.

WALTZ, Kenneth. Realism and international politics. New York and London: Routledge, 2008.

WEAVER, Ole. The rise and fall of the inter-paradigm debate In: SMITH, Steve; BOOTH, Ken; ZALEWSKI, Marysia. (Ed.). International theory: positivism and beyond. Cambridge: Cambridge University Press, 1996.

WENDT, Alexander E. The agent-structure problem in international relations theory. International Organization, v. 41, n. 3, p. 335-370, 1987.

WENDT, Alexander E. Anarchy is what States make of it: the social construction of power politics. International Organization, v. 46, n. 2, p. 391-425, 1992.

WENDT, Alexander E. Constructing international politics. International Security, v. 20, n. 1, p. 71-81, 1995. 